\title{
The Silviculture of Black Locust (Robinia pseudoacacia L.) in Hungary: a Review
}

\author{
Károly Rédei \\ Forest Research \\ Institute, \\ Püspökladány \\ Experimental Station, \\ Farkassziget 3, \\ 4150 Hungary \\ redei.karoly@t-online.hu
}

$\begin{array}{ll}\text { Imre Csiha } & \text { Zsolt Keserü } \\ \text { Forest Research } & \text { Forest Research } \\ \text { Institute, } & \text { Institute, } \\ \text { Püspökladány } & \text { Püspökladány } \\ \text { Experimental Station, } & \text { Experimental Station, } \\ \text { Farkassziget 3, } & \text { Farkassziget 3, } \\ \text { 4150 Hungary } & \text { 4150 Hungary }\end{array}$

Zsolt Keserü

Institute,

Farkassziget 3

4150 Hungary

\author{
Ágnes Kamandiné Végh Judit Győri \\ Forest Research \\ Institute, \\ Püspökladány \\ Experimental Station, \\ Farkassziget 3,
}

4150 Hungary

\section{Abstract}

Background and purpose: Black locust (Robinia pseudoacacia L.) was the first forest tree species introduced and acclimated from North America to Europe at the beginning of the $17^{\text {th }}$ century. Although native of North America, black locust is now naturalized and widely planted throughout the world from temperate to subtropical areas. In Hungary, this species has played a role of great importance in the forest management, covering approximately $23 \%$ of the forested area and providing about $19 \%$ of the annual timber output of the country. Due to the increasing interest in black locust growing in many countries, this study has been compiled with the aim of giving a summary on the basis of research and improvement connected with the species over the past decades.

Material and methods: Black locust forests in Hungary have been established on good as well as on medium and poor quality sites. Establishment of black locust stands producing timber of good quality is possible only on sites with adequate moisture and well-aerated and preferably light soils, rich in nutrients and humus. Black locust forests on medium and poor quality sites are utilized for the production of fuel wood, fodder, poles and props, as well as for honey production, soil protection and environmental improvement.

Results and conclusion: Hungary has got much experience in black locust growing, as it has been grown for more than 250 years in the country. It is a fast growing, nitrogen fixing, site tolerant, excellent coppicing species with frequent and abundant seed production and relatively high yielding potential. It has a durable and high quality wood, which is used for many purposes. Being aware of the importance of black locust, forest research in Hungary has been engaged in resolving various problems of black locust management for a long time, and a lot of research results have already been implemented in the practice.

Keywords: black locust (Robinia pseudoacaia L.), clone selection, stand establishment, tending operations and yield; dendromass production, diseases

\section{INTRODUCTION}

Black locust was introduced in Hungary between 1710 and 1720. The first large black locust forests were established at the beginning of the $18^{\text {th }}$ century on the Great Hungarian Plain stabilizing the windblown sandy soil. In the country, black locust occupied 37.000 ha in $1885,109.000$ ha in $1911,186.000$ ha in 1938 and 415.000 ha in 2009. At present, it is the most widely planted species in Hungary, covering $23 \%$ of the country's total forest area. One-third of these stands are high forests and two-third of them are of coppice origin. In the 1960s, Hungary had more black locust forests than the rest of European countries together [1-3].

Black locust forests in Hungary have been established on good as well as on medium and poor quality sites. Establishment of black locust stands producing timber of good quality is possible only on sites with adequate moisture and well-aerated and preferably light soils, rich in nutrients and humus. Black locust forests on medium and poor quality sites are utilized for the production of fuel wood, fodder, poles and props, as well as for honey production, soil protection and environmental improvement [54]. 
The most important black locust growing regions in Hungary are located in the south and south-west Transdanubia (hill-ridges of Vas-Zala county, hill-ridges Somogy county), the plain between the rivers Danube and Tisza (Central Hungary) and north-east Hungary (Nyírség region) (Figure1).

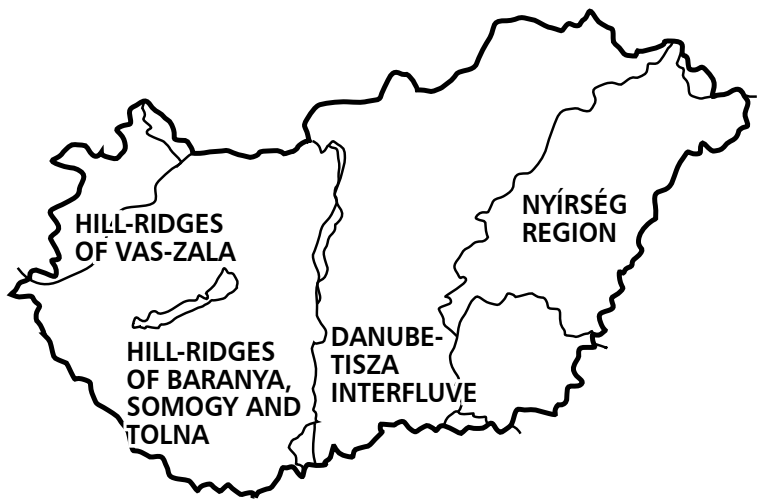

FIGURE 1

The main growing regions of black locust (Robinia pseudoacacia L.) stands in Hungary

\section{BLACK LOCUST SILVICULTURE}

\section{Geographic distribution and variability as well as physiological attributes of black locust}

Within the genus Robinia the species $R$. pseudoacacia L. black or common locust, and some of its varieties (shipmast locust - var. pyramidalis), and spineless locust are promised for forest tree breeding. Other varieties are rewarding with respect to breeding for honey prduction: early flowering (var. praecox), late flowering (var. galiana) and continuously flowering (var. semperflorens Car.), in addition two late flowering and abundantly nectarine spcies, $R$. luxurians (rich locust) and $R$. viscosa (sticky locust); and hybrids of the latter two species with black locust.

The species is indigenous to the eastern and central part of USA between latitudes $43^{\circ}$ and $35^{\circ} \mathrm{N}$. In its natural range tree types of black locust are distinguished by shape:

- Pinnata (feathered) type: the stem is straight. It occurs along the northern edge of the species' area at the elevation of about $800 \mathrm{~m}$ with Picea rubra and Acer saccarinum.

- Palmata (palm-like) type: the main part of the stem is crooked and not clearly visible in the crown. Its natural area is in the medium elevations of the Appalachians.

- Spreading type: it seems to be unsuitable for selection. It occurs at the low elevations of the Appalachians, and in the southern part of the natural area.
Physiological attributes of black locust are the followings:

- rapid growth rate, out-competes weeds,

- indeterminate growth habit,

- nodulated roots, fixes atmospheric $\mathrm{N}_{2}$

- high density wood,

- good pulping qualities,

- highly resistant to fungi, pests,

- tolerates low fertility sites,

- resistant to drought stress,

- resistant to air pollutants,

- resistant to low temperatures,

- resistant to high temperatures,

- very high net photosynthetic rates,

- high light demand,

- high leaf area accretion rate,

- high transpiration rate,

- rapid leaf position adjustment to changes in light intensity,

- $\quad$ small leaflets minimalize self-shading,

- vigorous sprouting of root cuttings,

- very plastic root system: strong tap and dense fibrous upper roots,

- flowers at early age,

- produces abundant seed crops,

- high seed viability and longevity,

- seeds easily cleaned, stored, sown,

- seeds germinate rapidly,

- easily micropropagated,

- high leaf protein,

- much genetic variation.

\section{Clone and cultivar selection}

In Hungary, the main goals of the first black locust breeding programme (in the 1960's) were to select new clones and cultivars providing good quality and volume of industrial wood. Superior tree groups have been identified in some seed grown stands. Graft material was taken from the plus trees and planted in test plots at Gödöllö (experimental station of FRI). Mono- and multiclonal cultivars were developed and a seed orchard was established from the selections. The Hungarian Forest Research Institute coordinated this research programme. With respect to the volume expected at felling age, the 'Jászkiséri', 'Kiscsalai', 'Nyírségi', 'Üllo" $i$ ' and 'Szajki' cultivars proved to be the best $[1,2,5]$.

In Hungary, the range of sites optimal for black locust growing is rather limited. Therefore, black locust growing is often exercised on sub-optimal sites. Possibilities for black locust growing are highly influenced by climatic conditions and extremes (temperature and precipitation, water supply and unfavourable soil conditions). In the lowlands, which are the most suitable regions for black locust growing, the annual precipita-

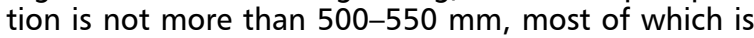
outside the growing season. Thus drought is a frequent phenomenon in the summer period coupled with very high atmospheric temperatures $\left(30-35^{\circ} \mathrm{C}\right)$. Relative air humidity in July is usually between $20-50 \%$. Due to the 
filling up of basin-like lowlands in Hungary, site conditions show a mosaic pattern, which changes even over small distances causing widely differentiated growth potential for black locust plantations. For this reason, there are no large, contiguous lands of homogenous site quality for black locust, and their growth and productivity may be very different across a large field. Therefore, the main aim of our new selection work is to find and improve black locust clones and cultivars, which perform good shape, provide good-quality wood material for industrial purposes, and which are able to tolerate the changing ecological conditions as well. As a result of our new selection programme 12 black locust clones ('KH 56A 2/5', 'KH 56A 2/6', 'MB 12D', 'MB 17D 4/1', 'CST 61A 3/1', 'MB 15A 2/3', 'MB $17 D 3 / 10^{\prime}$, 'PV 201E 2/1','PV 201E 2/3', 'PV 201E 2/4', ' $P V 35 B / 2$ ', and ' $P V 233 A / 2$ ') have been recommended $[6-9,10]$.

\section{Propagation}

In Hungary, black locust plants are commonly multiplied by two methods: by seed and by root cuttings. Growing trees from seed is a relatively simple method for reliably producing seedlings on a large scale under a variety of circumstances. There are two state approved seed production stand-regions meeting the requirements for black locust seeds (one in the plain between the rivers Danube and Tisza and the other in the Nyírség region) [11]. Seeds are collected by sieving the top $20 \mathrm{~cm}$ of soil beneath the selected seed-producing stands. As the seeds of black locust used to remain dormant in the soil for several years, the age of seeds within the lots collected in this way is very variable. This is the reason of viability and germination are so variable. Therefore, before sowing, an accurate seed test is necessary. Seed production for sowing and scarification is carried out by the agency responsible for collecting the seed. It is advisable to treat the seeds against fungi, and this is done in a small concrete mixer. 200-250 thousand seedlings of $40-90 \mathrm{~cm}$ high and $5-12 \mathrm{~mm}$ in base diameter are raised on one hectare. Mechanization of the method is easy and the production costs are relatively low.

Propagation from root cuttings is suitable for reproduction of superior individuals or varieties (cultivars). By applying this method, superior traits of the selected trees can be preserved in the clones. Production of plants in this way demands more care than raising seedlings from seeds. For this propagation method, root pieces cut into $8-10 \mathrm{~cm}$ or chopped to $3-5 \mathrm{~cm}$ in length are used. Plant spacing in the rows should be $5-8 \mathrm{~cm}$.

Almost 25 new cultivars or selected clones were micro-propagated during the last few years in the Micro-propagation Laboratory of Research Institute for Fruit growing and Ornamentals, Érd in collaboration with the Hungarian Forest Research Institute. Plant tissue culture methods provide us with new means to speed up vegetative propagation of recently selected clones and give us the opportunity to establish new clone trials and a seed orchard with them [7, $8,12]$.

\section{Stand establishment, forest tending and yield}

Climate, hydrology and soil types are the factors that determine the site type, and this in turn determines the choice of tree species. The water regime of the soil is also highly influenced by the texture of the soil, whether it is humus, coarse sand, loam or clay. Black locust - because of its high requirement for both water and aeration in the soil - cannot be grown even on any soil composed of humus, coarse sand or clay if the rooting depth is very shallow.

Black locust requires well-drained soils with adequate moisture until the associated nitrogen-fixing Rhizobium bacteria are able to thrive. That is why soil preparation (total or partial) to improve aeration and the water regime of the soil and tilling of the inter-row space may become necessary.

Black locust afforestation and artificial regeneration may utilise seedlings. The most popular spacing for black locust in Hungary is $2.4 \mathrm{~m}$ by 0.7 to $1.0 \mathrm{~m}$, requiring at least 4000 seedlings/ha. Black locust stands are often regenerated by coppice (from root suckers) as well. In young stands of coppice origin, a cleaning operation should be carried out to adjust spacing when the stands are 3-6 years old and should reduce stocking to less than 5000 stems/ha $[10,13]$.

The black locust is a fast-growing tree species, which, up to the age of 10-15 years, is able to close canopy openings caused by tending operations quickly, but the closure is much slower in later years. Height growth peaks within the first five years, while diameter growth culminates in the first decade. The peak of current annual increment is at about the age of 20, whereas that of the mean annual increment is at about the age of 35-40 years.

To find the right cleaning and thinning intensity, the so-called growing space index is a good method. This index expresses the mean distance between trees (in a triangular pattern) as a percentage of mean height after cleaning and thinning. The mean value of the index for black locust stands should be $23-24 \%$. Pruning of crop trees should also be carried out. After finishing selective thinning, stems must be free of branches up to a height of 4-6 m.

The objective of tending is to produce a high proportion of good quality saw-logs from stands of yield class I and II; some saw-logs and a high proportion of poles and props from stands of yield class III and IV; and poles, props and other small-dimension industrial wood from other yield stands [14-16]. 
TABLE 1

Tending regimes for high and coppice common black locust stands (Yield table: source [17])

\begin{tabular}{|c|c|c|c|c|c|c|c|}
\hline Operation & $\begin{array}{l}\text { Age } \\
\text { (yr) }\end{array}$ & Height (m) & $\begin{array}{c}\text { Basal area } \\
\left(\mathrm{m}^{2} / \mathrm{ha}\right)\end{array}$ & $\mathrm{DBH}(\mathrm{cm})$ & $\begin{array}{c}\text { Density } \\
\text { (stems/ha) }\end{array}$ & $\begin{array}{l}\text { Growing } \\
\text { space }\left(\mathrm{m}^{2}\right)\end{array}$ & $\begin{array}{l}\text { Volume cut } \\
\left(\mathrm{m}^{3} / \mathrm{ha}\right)\end{array}$ \\
\hline \multicolumn{8}{|l|}{ Yield Class I } \\
\hline Cleaning & 5 & 8 & 7 & 6 & 2500 & 2.1 & 6 \\
\hline Cleaning & 9 & 13 & 13 & 10 & 1700 & 2.6 & 20 \\
\hline Selective thinning & 12 & 16 & 12 & 13 & 900 & 3.6 & 30 \\
\hline Selective thinning & 18 & 20 & 17 & 19 & 600 & 4.4 & 35 \\
\hline Increment thinning & 25 & 24 & 18 & 24 & 400 & 5.4 & 50 \\
\hline Harvest cutting & 40 & 27 & 32 & 32 & 400 & 5.4 & 425 \\
\hline \multicolumn{8}{|l|}{ Yield Class II } \\
\hline Cleaning & 6 & 8 & 7 & 6 & 2500 & 2.1 & 5 \\
\hline Cleaning & 10 & 12 & 13 & 10 & 1700 & 2.6 & 20 \\
\hline Selective thinning & 15 & 16 & 14 & 14 & 900 & 3.6 & 35 \\
\hline Increment thinning & 22 & 20 & 17 & 20 & 550 & 4.6 & 45 \\
\hline Harvest cutting & $35-40$ & 23 & 29 & 26 & 550 & 4.6 & 340 \\
\hline \multicolumn{8}{|l|}{ Yield Class III } \\
\hline Cleaning & 7 & 8 & 7 & 6 & 2700 & 2.5 & 4 \\
\hline Cleaning & 12 & 12 & 14 & 10 & 1800 & 2.5 & 15 \\
\hline Selective thinning & 17 & 15 & 16 & 14 & 1100 & 3.3 & 35 \\
\hline Increment thinning & 22 & 18 & 17 & 17 & 700 & 4.1 & 40 \\
\hline Harvest cutting & 30 & 20 & 26 & 22 & 700 & 4.1 & 270 \\
\hline \multicolumn{8}{|l|}{ Yield Class IV. } \\
\hline Cleaning & 8 & 8 & 8 & 6 & 3000 & 1.8 & 4 \\
\hline Cleaning & 13 & 11 & 15 & 10 & 2000 & 2.4 & 15 \\
\hline Selective thinning & 19 & 14 & 13 & 13 & 1000 & 3.4 & 35 \\
\hline Harvest cutting & 30 & 17 & 25 & 18 & 1000 & 3.4 & 235 \\
\hline \multicolumn{8}{|l|}{ Yield Class V } \\
\hline Cleaning & 9 & 7 & 7 & 7 & 3000 & 1.8 & 4 \\
\hline Cleaning & 15 & 10 & 9 & 9 & 1500 & 2.8 & 20 \\
\hline Harvest cutting & 25 & 14 & 20 & 13 & 1500 & 2.8 & 155 \\
\hline \multicolumn{8}{|l|}{ Yield Class VI } \\
\hline Cleaning & 10 & 6 & 7 & 5 & 3500 & 1.6 & - \\
\hline Cleaning & 15 & 8 & 8 & 7 & 2000 & 2.4 & 15 \\
\hline Harvest cutting & 20 & 10 & 12 & 9 & 2000 & 2.4 & 70 \\
\hline
\end{tabular}

On Table 1 the most important stand structure and yield factors of black locust main crops (height, basal area, DBH, stem number, growing space and volume cut) can be seen.

The yield and stand structure of black locust stands can be described by the following formulas and coefficients:

\footnotetext{
1. $\mathrm{H}=$ mean height of the main crop weighted by the basal area $(\mathrm{m})$ :

$\mathrm{H} \%=123.12\left(1-\mathrm{e}^{-0,070333 \mathrm{~A}}\right)^{1.111638}$ where $A=$ age of stand in years;

$\mathrm{H}$ at the age of $20=100 \%$
}

2. $\mathrm{DBH}=$ the diameter at breast height of

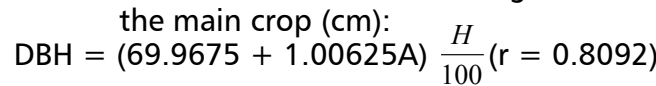

$\mathrm{N}=$ number of stems per hectare of the main crop: $\mathrm{N}=\mathrm{e}^{9.81801-1.15147 \times \operatorname{lnDBH}}(r=0.9421)$

According to our yield table [17] the volume of main crop varies between 80 and $280 \mathrm{~m}^{3} /$ ha in function of yield classes at the age of 30 years, which is the average rotation age for black locust stands in Hungary. The black locust stands of Yield Class I-II have a rotation of 35-40 years and an annual incre- 

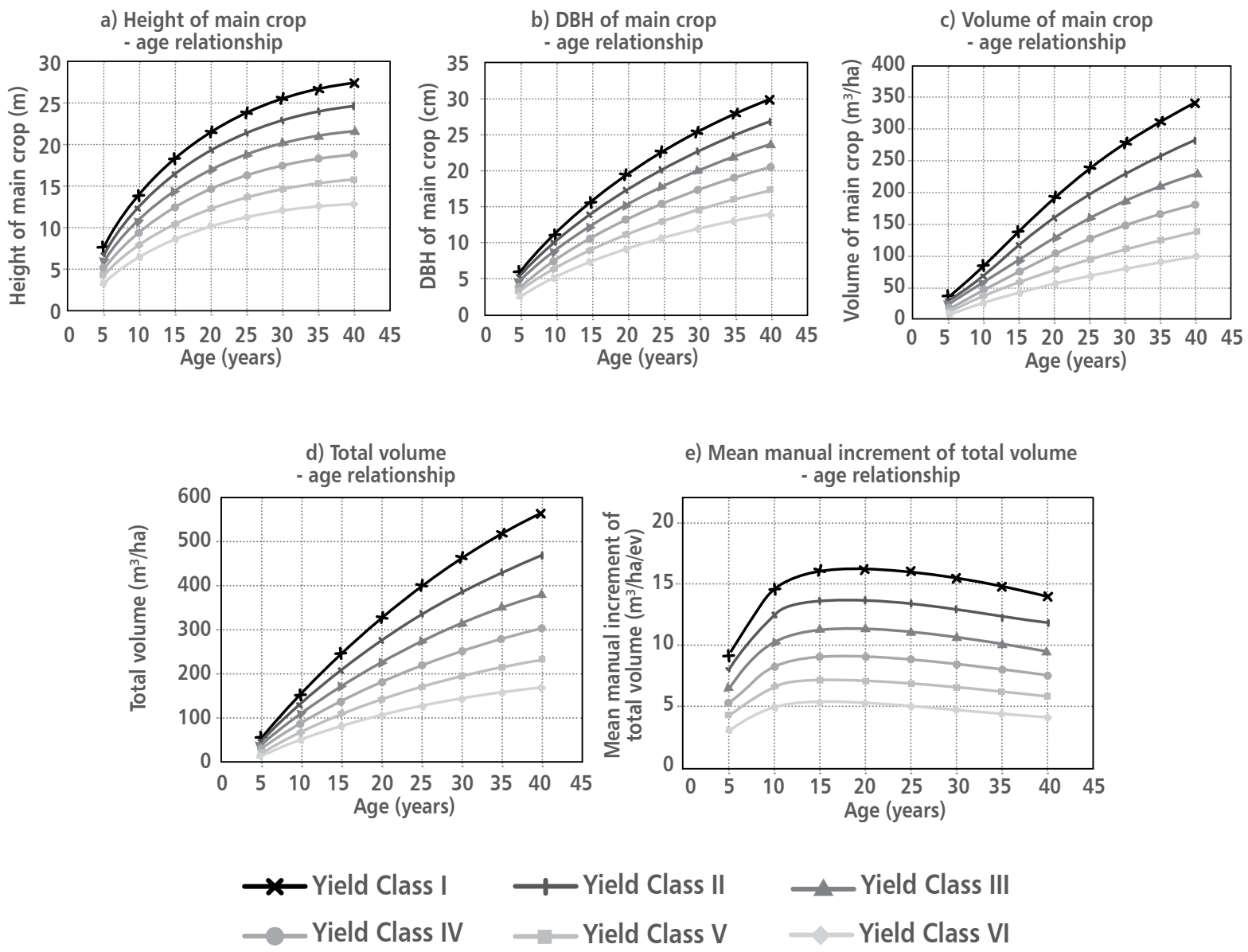

\section{FIGURE 2}

Black locust stand structure factors in function of age (Yield table: source [17])

ment of total volume of $12-14 \mathrm{~m}^{3} \mathrm{ha}-1 \mathrm{yr}^{-1}$. The stands of Yield Class III-IV have a rotation of 30 years and an annual increment of 8-9 $\mathrm{m}^{3} \mathrm{ha}^{-1} \mathrm{yr}^{-1}$. Finally, the poorest stands (Yield Class V-VI) have a rotation of 20-25 years and an annual increment of 4-6 $\mathrm{m}^{3} \mathrm{ha}^{-1} \mathrm{yr}^{-1}$ (Figure 2). In first generation coppice stands, growing stock, increment and health are similar to those in high forests.

\section{Black locust short rotation forestry}

More and more agricultural land is being taken out of use for food crops, some of which can be used for wood energy production plantations. Black locust is the very best tree species for this purpose, since it has excellent energy production properties, such as:

- vigorous growing potential in juvenile phase,

- excellent coppicing ability,

- $\quad$ high density of the wood,

- high dry matter production,

- favourable combustibility of the wood,

- relatively fast drying,

- $\quad$ easy harvesting and wood processing.
In the last decade several energy producing plantations have been established in Hungary. In these experiments, several spacing treatments were tested and the common black locust as well as its cultivars were compared.

In Helvécia (central Hungary, sand-soil region) an energy plantation was established using common black locust and its cultivars. The various spacings of the common black locust were: $1.5 \times 0.3 \mathrm{~m}, 1.5 \times 0.5 \mathrm{~m}$ and $1.5 \times 1.0 \mathrm{~m}$.

Results concerning the trial with cultivars and common black locust at the age of 3,5 and 7 are provided in Table 2 and focused on the differences in the values of the mean annual increment of oven - dry stem dendromass in Figure 3. At the age of 5, the highest increment value was produced by the cultivar 'Ullo'i' ( 8.0 to $\left.\mathrm{ha}^{-1} \mathrm{yr}^{-1}\right)$, followed by 'Jászkiséri' (7.4 to $\left.\mathrm{ha}^{-1} \mathrm{yr}^{-1}\right)$ and the common black locust $\left(6.7\right.$ to $\left.\mathrm{ha}^{-1} \mathrm{yr}^{1}\right)$. At the age of 7, the order was the following: 'Ullo'i i' cultivar (9.7 to $\left.\mathrm{ha}^{-1} \mathrm{yr}^{-1}\right)$, common black locust (8.4 to $\mathrm{ha}^{-1} \mathrm{yr}^{-1}$ ) and Jászkiséri' cultivar (7.6 to ha-1 $\left.\mathrm{yr}^{-1}\right)$. 


\section{TABLE 2}

Evaluation of a short-rotation plantation with black locust cultivars on the base of plot averages (Helvécia 80/A); Stem number $=6666$ per ha, $H=$ height, $D B H=$ diameter at the breast height $(1.3 \mathrm{~m})$.

\begin{tabular}{|c|c|c|c|c|c|}
\hline \multirow[b]{2}{*}{ Cultivars } & \multirow[b]{2}{*}{ Age (yr) } & \multicolumn{2}{|c|}{ Mean } & \multirow{2}{*}{$\begin{array}{l}\text { Oven-dry stem } \\
\text { dendromass } \\
(\text { to ha-1) }\end{array}$} & \multirow{2}{*}{$\begin{array}{l}\text { Mean annual } \\
\text { in-crement of } \\
\text { oven-dry stem } \\
\text { dendromass } \\
\left(\text { to ha-1 } \mathrm{yr}^{-1}\right)\end{array}$} \\
\hline & & $\mathrm{H}(\mathrm{m})$ & $\mathrm{DBH}(\mathrm{cm})$ & & \\
\hline \multirow{3}{*}{ 'Üllöi' } & 3 & 4.1 & 3.1 & 8.9 & 3.0 \\
\hline & 5 & 6.2 & 4.9 & 40.1 & 8.0 \\
\hline & 7 & 9.3 & 6.4 & 68.1 & 9.7 \\
\hline \multirow{3}{*}{ 'Jászkiséri' } & 3 & 3.6 & 2.9 & 7.1 & 2.4 \\
\hline & 5 & 6.1 & 4.7 & 37.1 & 7.4 \\
\hline & 7 & 8.8 & 6.2 & 53.2 & 7.6 \\
\hline \multirow{3}{*}{ 'Nyírségi' } & 3 & 3.1 & 2.7 & 7.2 & 2.4 \\
\hline & 5 & 5.3 & 4.2 & 28.4 & 5.7 \\
\hline & 7 & 7.6 & 5.1 & 46.2 & 6.7 \\
\hline \multirow{3}{*}{ 'Kiscsalai' } & 3 & 3.9 & 3.2 & 12.5 & 4.2 \\
\hline & 5 & 6.1 & 4.6 & 31.1 & 6.2 \\
\hline & 7 & 8.4 & 5.9 & 49.7 & 7.1 \\
\hline \multirow{3}{*}{$\begin{array}{c}\text { Common black } \\
\text { locust }\end{array}$} & 3 & 3.7 & 3.1 & 10.9 & 3.6 \\
\hline & 5 & 6.1 & 4.7 & 33.5 & 6.7 \\
\hline & 7 & 8.2 & 5.5 & 59.1 & 8.4 \\
\hline
\end{tabular}

The data from the Table 2 and the Figure 3 indicate that it is not reasonable to harvest the plantations in the first three years, as the mean annual increment of oven-dry sterm dendromass at the age of 5 and 7 is 1.5-3 times higher than it was at age of 3 . This result is important as it is known that too early harvesting may also increase the population of biotic pests [18] .

According to the significance test at $\alpha=5 \%$ level, significant differences were found in the mean annual increment of oven - dry stem dendromass $\left(\mathrm{F}=40.991>\mathrm{F}_{0.05}=3.422, \mathrm{SD}_{5 \%}=0.69 \mathrm{~m}^{3} \mathrm{ha}^{-1} \mathrm{yr}^{-1}\right)$. To compare the concerning yields produced by the black locust clones and the common black locust, it is no worth using expensive black locust clonal material for setting up short rotation plantation.

Black locust energy forests can also be established by coppicing. Advantages of energy forests of coppice origin are that the cost of establishment is low compared to that of soil preparation, plantation and cultivation. From the developed root system of the previous stand, a large dendromass can be produced within a short time period. Disadvantages of these forests are that the area distribution of trees in coppice stands is not as uniform as in plantations optimized for energy production. In coppice stands the quantity of the produced dendromass is lower and the length of growing time is highly influenced by the uneven distribution of stems.

The first peak of the annual increment in volume of black locust energy forests established from sprouts

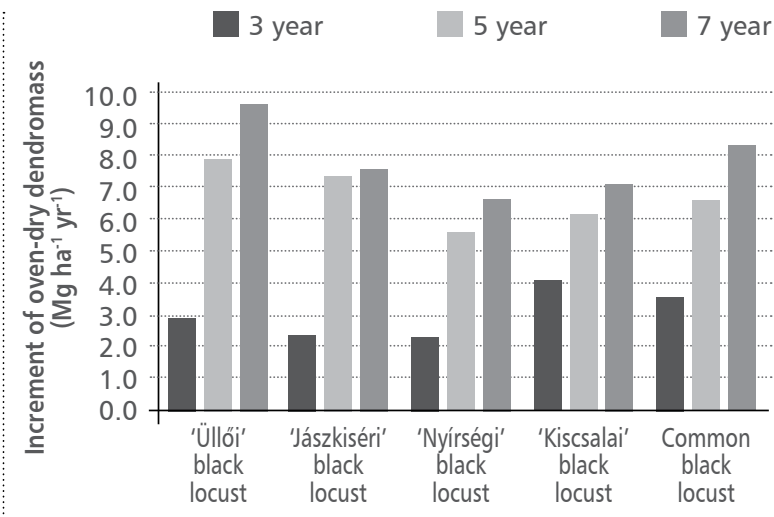

FIGURE 3

Mean annual increment of oven-dry stem dendromass of black locust cultivars and common black locust at different ages

falls between the age of 3 and 5 years. Then, the annual increment declines and a new peak occurs between age of 9 and 12 years. A further maximum is expected later on, at about 15 years because of an even higher degree of mortality. Approximately one-third of the stems are lost at age 7 and 8 . By the 12-13 years, the stem numbers decreased to less than $50 \%$.

The experiences from both the planted and the coppiced energy plantations and other stands indicate that it is not reasonable to harvest in the first three years, as the yield in oven-dry weight in the fifth year 
is 2-3 times higher than it is in the fourth year. Harvesting too early may also increase the population of biotic pests [18-20].

\section{Diseases, insects, and other damaging agents of black locust}

Regarding the abiotic damages, frost damage can be considered as the most important factor (early and late frosts, hard winter frosts). Black locust is seems to be good disease and pest resistant. However in the ultimate time more and more potential pests have appeared in the European black locust forests. Several fungi infects black locust, specially the seeds and seedlings, for example Alternaria tenuis (NEES) or Fusarium oxysporum (SCHLECHTENDAHL). In case of biotic damages we have to mention the damages caused by pests; such as Black bean aphid (Aphis fabae SCOPOLI).

Black locust scale (Parthenoclanium corni BOUCHÉ), Black locust leafminor (Phyllonorycter robiniella CLEMENS), or Cotton bollworm (Helicoverpa armigera HÜBNER). Game damage can also cause relative high shortfall in the annual increment. Main part of game damage is caused by rabbit and deer. Rabbits are peeling off the bark of young trees, deer and roe deer like browsing the fresh shoots and buds.

\section{CONCLUSIONS}

Black locust was the first forest tree species introduced from North America to Europe. Hungary has got much experience in black locust growing, as it has been grown for more than 250 years in the country. Being aware of the importance of black locust, forest research in Hungary has been engaged in resolving various problems of black locust management for a long time, and a lot of research results have already been implemented in the practice.

In the future there are two bigger regions, where the fast spread of black locust can be expected. In Europe the Mediterranean countries (Italy, Greece, Spain and Turkey), while in Asia China and Korea may become the most prominent black locust growers.

\section{ACKNOWLEDGEMENTS}

Research on black locust improvement in Hungary is partly supported by the project called Multidisciplinary integrated approach for the improvement and sustainable use of Robinia pseudoacacia clones (CNR, Italy MTA, Hungary). Further support has been provided by the Hungarian Ministry of Rural Development, Budapest and by the Nyírségi Forestry Joint Stock Company (Nyíregyháza) through fruitful field work cooperation.

\section{REFERENCES}

1. KERESZESI B 1983 Breeding and cultivation of black locust (Robinia pseudoacacia L.) in Hungary. Forest Ecol Manag 6 (3): 217-244

2. KERESZTESI B (Ed.) 1988 The Black Locust. Akadémiai Kiadó, Budapest

3. RÉDEI K 1991 Management of Black Locust Stands in Hungary. $10^{\text {th }}$ World Forestry Congress. Voluntary Contributions. Paris, Proceeding 4, p 289-294

4. RÉDEI K 1986 Waldpflege in den ungrischen Robinienwäldern. Die Holzzucht 40 (1-2): 1-4

5. RÉDEI K, OSVÁTH-BUJTÁS Z, LEE J 2002 Selection and management of black locust (Robinia pseudoacacia L.) in Hungary for timber and honey production and landscapes. $J$ Kor Forest Soc 91: 156-162

6. RÉDEI K 2001 The main characteristics of black locust (Robinia pseudoacacia L.) management in Hungary. Third Balcan Scientific Conference. Proceeding, Sofia, p 293-300

7. RÉDEI K, OSVÁTH-BUJTÁS Z, BALLA I 2001 Vegetative Propagation Methods for Black Locust (Robinia pseudoacacai L.) Improvement. Hungarian Agricultural Research 10 (2): 6-9

8. RÉDEI K, OSVÁTH-BUJTÁS Z, BALLA I 2001 Propagation methods for black locust (Robinia pseudoacacia L.) improvement in Hungary. Journal of Forestry Research 12 (4): 215-219

9. RÉDEI K, OSVÁTH-BUJTÁS Z, BALLA I 2002 Clonal approaches to growing black locust (Rominia pseudoacacia) in Hungary: a review. Forestry 75 (5): 548-552

10. RÉDEI K (Eds.) 2003 Black Locust (Robinia pseudoacacia L.) Growing in Hungary. FRI Publication, Budapest

11. RÉDEI K, OSVÁTH-BUJTÁS Z, VEPERDI I 2006 Black locust (Robinia pseudoacacia L.) clonal seed orchards in Hungary. For Stud China 8 (4): 47-50
12. RÉDEI K 2002 Improvement of Black Locust (Robinia pseudoacacia L.) in Hungary. IUFRO Meeting on the Management of Fast Growing Plantations. Izmit, Turkey, Proceeding, p 166-173

13. REDEI K 1996 Yield study relations of regeneration of Robinia (Robinia pseudoacacia L.) stands. In: Sovsgaard J P, Johannsen V K (eds) Modelling Regeneration Success and Early Growth of Forest Stands. Proceedings form the IUFRO Conference, Hoersholm, p 105-111

14. RÉDEI K 1992 Management of Black Locust Stands in Hungary. Proceedings: International Conference on Black Locust. East Lansing (MI), p 38-43

15. RÉDEI K, MEILBY H 2000 Effect of thinning on the diameter increment in black locust stands (Robinia pseudoacacia L.). Silva Gandavensis 65: 115-127

16. RÉDEI K, OSVÁTH-BUJTÁS Z, VEPERDI I, BAGAMÉRY G, BARNA T 2007 La gestion du robinier en Hongrie. Foret enterprise 177 (5): 44-49

17. RÉDEI K 1984 Akácosok fatermése. (Yield of Black Locust Stands). FRI Research Report, Budapest

18. RÉDEI K 2000 The Role of Black Locust (Robinia pseudoacacia L.) in Establishing Wood Energy Plantation. Hungarian Agricultural Research 9 (4): 4-7

19. HALUPA L, RÉDEI K 1992 Establishment of forests primarily for energetic purpose. Erdészeti Kutatások 82-83, 267-286

20. RÉDEI K, VEPERDI I, TOMÉ M, SOARES P 2010 Black Locust (Robinia pseudoacacia L.) Short - Rotation Energy Crops in Hungary: a Review. Silva Lusitana 18 (2): 217- 223 